\title{
Similarities in Acquired Factors Related to Postmenopausal Osteoporosis and Sarcopenia
}

\author{
Joonas Sirola ${ }^{1,2}$ and Heikki Kröger ${ }^{1,2}$ \\ ${ }^{1}$ Department of Orthopedics, Traumatology and Hand Surgery, Kuopio University Hospital, 70211 Kuopio, Finland \\ ${ }^{2}$ Bone and Cartilage Research Unit (BCRU), University of Eastern Finland, 70211 Kuopio, Finland
}

Correspondence should be addressed to Joonas Sirola, joonas.sirola@kuh.fi

Received 27 April 2011; Revised 29 June 2011; Accepted 1 July 2011

Academic Editor: Jun Iwamoto

Copyright ( 12011 J. Sirola and H. Kröger. This is an open access article distributed under the Creative Commons Attribution License, which permits unrestricted use, distribution, and reproduction in any medium, provided the original work is properly cited.

\begin{abstract}
Postmenopausal population is at increased risk of musculoskeletal impairments. Sarcopenia and osteoporosis are associated with significant morbidity and social and health-care costs. These two conditions are uniquely linked with similarities in pathophysiology and diagnostic methods. Uniform diagnostic criteria for sarcopenia are still evolving. Postmenopausal sarcopenia and osteoporosis share many environmental risk- and preventive factors. Moreover, geriatric frailty syndrome may result from interaction of osteoporosis and sarcopenia and may lead to increased mortality. The present paper reviews the factors in evolution of postmenopausal sarcopenia and osteoporosis.
\end{abstract}

\section{Introduction}

One of the biggest challenges for public health care is the maintenance of health, independence, and mobility as well as prevention and postponement of disability of the aging population [1]. There are sex dependent differences in morbidity and disability among the elderly population which become more evident with age [2, 3]. Among middleaged women, menopausal transition, caused by physiological exhaustion of ovarian function $[4,5]$, evokes increase in musculoskeletal, cardiovascular, and mental impairments and cancer [6-8]. This increased female vulnerability related to aging, together with predominance of female elderly population, makes them an important target for research and preventive health care measures [7].

Sarcopenia, that is, muscle wasting, and osteoporosis, that is, fragile bone disease, are significant health burdens among the postmenopausal women. The prevalence of sarcopenia has been reported to be $10 \%$ to $40 \%$ in postmenopausal population depending on the reference method used and the population [8]. Osteoporosis affects approximately $30 \%$ of female population over 50 years [9]. Sarcopenia results in decline in activities of daily living, quality of life, and self-rated health and increases falls and related skeletal fractures [10-15] which have been estimated to have deep impact of social and healthcare-related costs of the postmenopausal population [16-19].

The present paper focuses on similarities in acquired factors associated with postmenopausal osteoporosis and sarcopenia concentrating on decades after the menopausal transition. Consequently, essential aspects on the effects of aging on sarcopenia and osteoporosis will be covered.

\section{Contemporary Definition of Sarcopenia and Osteoporosis}

Evaluation of the evidence behind the synergism between postmenopausal sarcopenia and osteoporosis requires a clear definition for both conditions. Unfortunately, uniform criteria for sarcopenia are still evolving, and methods as well as different measurement cutoffs have been used across studies. Majority of the diagnostic thresholds for sarcopenia have been developed based on muscle mass measurements with similar methods applied for diagnosis of osteoporosis. Moreover, the diagnosis of osteoporosis has shifted from 
salience of DXA towards independent risk factors for osteoporosis.

2.1. Sarcopenia. Among the elderly, genetics, hormonal changes, and lifestyle factors related to physical activity and nutritional factors have been linked to development of sarcopenia. From physiologic viewpoint, these lead to alterations in muscle protein turnover, muscle tissue remodeling, loss of alpha motor neurons, muscle cell recruitment, apoptosis, and muscle's fat content [20-22]. The multifactorial etiology of sarcopenia emphasizes and differentiates the three divisions of sarcopenia, that is, muscle mass, muscle strength, and muscle function. Conceptually, this is supported by the evidence that muscle strength does not correlate directly with muscle mass, and the relationship between strength may not be linear $[23,24]$. In fact, some have argued, that with regards to terminology, dynapenia would be a better acronym to describe age-related decline in muscle strength and function [25]. This, however, has not yet been uniformly incorporated into clinical use.

Sarcopenia is a syndrome characterized by progressive and generalized loss of skeletal muscle mass and strength with a risk of adverse outcomes related to physical ability, quality of life, or even death [23, 26]. According to the consensus of the European Working Group on Sarcopenia in Older People (EWGSOP), sarcopenia may be categorized into presarcopenia (loss of muscle mass), sarcopenia (loss of muscle mass and strength or functional ability), and severe sarcopenia (loss of muscle mass, strength, and functional ability) [20]. This categorization may be considered clinically sound and holistically aligns the concept of multiple facets of muscle wasting.

There are several methods for assessment of muscle mass, strength, and function. Muscle mass may accurately be assessed by dual X-ray absorptiometry (DXA) with very low radiation dose (1-2 micro-Sieverts). The operational definitions of sarcopenia have generally used DXA-based skeletal muscle mass index (SMI) [27]. Muscle mass below 2 SD of the mean of young reference population has been considered pathognomic for sarcopenia. Other methods available for assessment of muscle mass include bioimpedance analysis (BIA) [28-31], magnetic resonance imaging (MRI), and computed tomography (CT) $[32,33]$. In addition, anthropometric measurements, such as calf circumference, arm circumference, and skin fold thickness, may be used for evaluation of muscle mass $[27,34]$.

Muscle strength may be measured by variety of methods. Grip strength has been found to be a reproducible method for assessment of muscle strength [35-37]. Isometric knee extensor strength has also been commonly used for assessment of muscle strength and has shown feasibility in frail older subjects $[38,39]$, although there is limited reference data available [40-42].

The international working group has recently recommended a series of tasks, entitled short physical performance battery (SPPB) as the standard evaluation of physical performance in research and clinical use $[43,44]$. Other physical performance tests routinely used among the elderly include gait speed [43], timed get-up-and-go test (TGUG) [45], stair climb power test (SCPT) [46].

2.2. Osteoporosis. Osteoporosis affects approximately $30 \%$ of the postmenopausal population. Osteoporosis is characterised by reduced bone mineral density (BMD) [47-51] and increased rate of bone loss [52]. The main determinants of BMD are the peak bone mass achieved by early adulthood, the bone loss associated with age, and menopause in women $[53,54]$. Although the risk of fractures is greater among women with low BMD, it explains only part of the increased fracture tendency among the elderly [55]. This suggests that also other BMD-independent risk factors should be taken into account while evaluating the risk of fragility fractures [56]. The pathophysiology behind osteoporosis is, as with sarcopenia, multifactorial. Genetics, nutritional factors, lifestyle factors, and comorbidities have been shown to be associated with the disease [55-57]. In addition, factors related to falls have independent role in development of fragility fractures.

By definition, osteoporosis is a disease of increased skeleton fragility accompanied by low BMD and microarchitectural deterioration [58]. The golden standard for measuring bone material properties in clinical practice is axial DXA measurement from femur and spine. Bone mineral density (BMD) lower than -2.5 SD below the young adults is considered osteoporotic and BMD between -1 and -2.5 osteopenic. Peripheral methods, for example, peripheral quantitative computed tomography (pQCT) for assessment of bone microarchitectural properties, have been developed, but they have not supplanted central DXA as diagnostic method.

\section{Interaction between Postmenopausal Sarcopenia and Osteoporosis: The Potential Role of Common Acquired Risk Factors}

Sarcopenia and osteoporosis have been thought to coexist [59]. Several studies have shown a positive association between lean mass and BMD in postmenopausal women [60-62]. Appendicular skeletal muscle-mass-related relative skeletal muscle mass index (RSMI), which has been used for definition of sarcopenia, has been suggested to be positively related to BMD [63]. The correlation of RSMI with BMD, however, may be significantly affected by differences in physical activity [63]. Nevertheless, the positive association between sarcopenia and osteoporosis has not been shown constantly across different studies [64]. Classically, it has been suggested that changes in bone mass are mediated through interaction with muscle strain via the sensory function of osteocytes [65]. This mechanostat theory has also emphasized the substantial role of estrogen in controlling the muscle-bone unit which makes postmenopausal women an especial target of interest. Consequently, there seem to be several factors that significantly contribute to the interaction between sarcopenia and osteoporosis.

The evidence behind the synergism between sarcopenia and osteoporosis should be viewed from the perspective of 
the three modalities of sarcopenia, that is, muscle mass, strength, and function and the two modalities of osteoporosis, that is, BMD and fractures. Essentially, this interaction should also be considered from the view of common etiologic risk- and preventive factors. Indeed, many such factors are closely related to menopausal transition and age group of the postmenopausal population. The following paragraph concentrate on the common etiologic factors excluding secondary factors related to specific morbidities.

3.1. Genetics. Muscle and bone tissues have common mesenchymal precursor $[66,67]$. During the growth, bone and muscle tissues exert significant allometry $[68,69]$. Thereafter, during the adulthood, the functional properties between the two components of musculoskeletal system are functionally closely associated, and bone loss as well as muscle strength are positively correlated [70]. In the late years of the lifespan, the loss of both muscle and bone tissue shows parallel decline and may have genetic control $[66,71]$. There are several gene candidates involved in the genetic control of musculoskeletal interactions [72-74] which are holistically reviewed in detail recently [69]. However, the whole process of maturation, development, and decline of musculoskeletal system is significantly affected, besides genetics, by environmental factors [75].

The heritability of lean mass, measured with DXA, has been estimated to vary between $56 \%$ and $84 \%$ [76, 77]. With regards to muscle strength and power, genetic effects explain $30 \%-50 \%$ in postmenopausal age group [77, 78]. Analogously, the heritability of bone strength, measured with section modulus of femoral neck, has been reported to be 40 to $55 \%$ [76]. Lean mass and areal BMD seem to have common genetic effects that contribute to the interaction between these traits $[76,79]$. This association is likely to be multigenetic. A recent study found that muscle crosssectional area and structural bone strength share genetic effects in the postmenopausal age group [80].

To conclude, components of muscle and bone strength are significantly controlled by genes. Furthermore, bone and muscle strength may essentially share genetic effects.

3.2. Aging and Hormonal Changes in Menopause. Peak muscle strength is achieved in the early 40 s after which muscle strength gradually declines $[81,82]$. After the age of 50, muscle mass has been reported to decline $1-2 \%$ per year [83] and muscle strength $1.5 \%$ to $3 \%$ per year [84-87]. Elderly women lose muscle performance more rapidly than do their male counterparts $[88,89]$. It has been estimated that the decline of muscle strength attributable to the menopause accounts for an approximately $10-15 \%$ extraloss in addition to that purely related to age $[88,89]$. The loss of muscle strength during the menopause has been linked to estrogen depletion [90, 91], evoked by exhaustion of ovarian function during the perimenopausal years. Plasma estrone and estradiol levels have been reported to be associated with muscle mass in women [92]. This effect may be mediated directly through estrogen receptors in skeletal muscle [93] or indirectly through the effects of proinflammatory cytokines [94]. In addition, it has been shown that hormone therapy maintains muscle strength and performance [95-98] although this affect has not been observed constantly across studies [99, 100]. The natural menopausal transition seems, however, not to accelerate the decline in functional ability (such as get-up-and-go test or modified Cooper test) to the same extent in comparison to muscle strength [88]. These findings emphasize the different roles of muscle mass, strength, and function in development and evaluation of sarcopenia. In addition to menopause-related female hormonal changes, several other mechanisms, related to hormonal changes, accumulation of free radicals, nutrition, and physical activity among the others, may also contribute to sarcopenia in aging population which partly occurs simultaneously with menopause [91]. Consequently the exact contribution and mechanism by which menopause affects muscle tissue is still not fully resolved.

Menopausal transition is the most important and inevitable single factor in the evolution of postmenopausal osteoporosis $[53,54]$. At the beginning of menopause, the acute loss of the restraining effect of estrogen on receptors on the membranes of osteoblasts and osteoclasts leads to accelerated bone turnover, uncoupling bone formation from resorption [101-103]. The closer molecular mechanisms of estrogen-depletion-related bone loss have been linked to the overproduction of bone resorptive cytokines (RANKL) [103]. In addition, imbalance between calcium secretion and absorption following the estrogen depletion has been suggested to influence the accelerated bone loss rate [104]. It has been shown that menopausal transition is associated with both increased bone loss rate, reduced BMD, and increased fracture incidence [105-110]. The phase of the most accelerated bone loss takes place at the very beginning of menopause (amenorrhea phase) after which the bone loss rate becomes progressively diminished for several years during the early postmenopause [105-111]. Some differences have been observed in the pattern of menopausal bone loss between different skeletal sites which may be related to the different composition of these sites with respect to cortical and trabecular bone $[112,113]$. Perimenopausal bone loss rates of over -2 percent/year in spinal and over -1 percent/year in the femoral region have generally been reported $[105,106,110,111,114]$. In postmenopausal women, age-related bone loss continues at age-specific rate after the initial fastening during the menopausal transition [112]. In women over the age of 60 years, the risk of fracture has been shown to increase $6 \%$ per year [115]. The significant role of female hormones for bone health is further supported by the finding that HT prevents postmenopausal bone loss and decreases the risk of fractures [116-120] with 34\% reduction in vertebral and 13\% reduction in nonvertebral fracture incidence [121].

To conclude, female hormones essentially regulate both muscle and bone health during the postmenopause and thus play significant role in development of sarcopenia and osteoporosis. These may be, to some extent, prevented by HT. Aging aggravates the effects of estrogen depletion on bone and muscle loss. 
3.3. Body Weight and Composition. In postmenopausal age group, there is a significant positive correlation between body weight, fat mass, lean tissue mass with BMD [70]. However, there are some specific differences in response of muscle and bone tissue to weight, weight change, and fatness.

In healthy young subject, bone and muscle grow in harmony with weight increase because of gravity-stimulated mechanoreceptors [122, 123]. However, being overweight impairs physical activity in all age groups. High BMI has been previously found to predict poorer quality of life particularly in the areas of physical functioning and health perceptions $[124,125]$. Increase in BMI in postmenopausal population is predominantly due to increase in fat mass with significantly lower contribution of lean mass [126]. The increased prevalence of functional limitations and disability with increasing BMI has been repeatedly reported, although the relative increase in muscle mass with increasing BMI might explain some discrepancies between genders [127-130]. The decline in physical activity due to obesity may contribute to the development of sarcopenia [131]. In addition, the fat and muscle tissue may be inversely controlled through certain metabolic pathways, including inflammatory cytokines [132], insulin resistance [133, 134], and effects of growth hormone [135]. These factors may result in condition termed "sarcopenic obesity" [136, 137]. The prevalence of sarcopenic obesity has been suggested to be around 4 to 12 percent $[136,138]$. Sarcopenic obesity has been proposed to be associated with disability and functional decline $[138,139]$. Other studies, however, have linked this disability to only obesity itself [138].

Weight loss has been suggested to contribute to the development in sarcopenia in aging population although it has been argued that, during weight change, a greater proportion of lean mass than fat mass is conserved [140]. However, weight loss interventions combining adequate diet and exercise have been suggested to improve muscle strength and quality with simultaneous fat loss [141]. This also aligns the conception that there is a tight connection between adiposity and muscle function. Weight-loss-related bone loss has been found to be reduced in postmenopausal subjects with good muscle strength [142].

Body weight and weight changes are positively linked to $\mathrm{BMD}$ and its changes in postmenopausal women. Weight and weight increase are associated with the maintenance of BMD and reduced bone loss whereas thinness and weight loss lead to low BMD and enhanced bone loss in early and later postmenopause [143-145]. In addition, high body weight is a strong independent predictor of lower postmenopausal fracture incidence, especially of the hip [146]. These effects may partly be linked with fat-tissue-related estrogen production [5]. It has been found that HT may counteract weight-loss-related bone loss in postmenopausal women, which supports the role of estrogen in fat-bone interaction [147]. Mechanical load as such is likely to lead to bone strengthening with mobility-induced weightbearing stress. In addition, hormones that regulate fat tissue metabolism, leptins, have been suggested to be involved in the regulation of bone metabolism $[148,149]$. The heavier population also has a higher nutritional intake and may thus consume more calcium and other bone-preserving products. In addition, the differentiating role of muscles and fat in weight-related bone mass changes remains unclear. It has been hypothesized that lower hip fracture incidence among the obese is related to higher soft tissue padding, not bone strength itself [150]. Indeed, increased fracture risk in appendicular sites has been linked to obesity [150]. Part of the observed BMD changes related to weight alterations may be due to methodological difficulties encountered in the measurement techniques adopted to deal with body compositional factors, most importantly fat tissue $[62,151]$.

To conclude, fatness is related to higher lean and bone mass, and weight loss generally causes bone and muscle loss in postmenopausal age group. However, obese women may have unique etiology behind sarcopenia (sarcopenic obesity) and increased risk of osteoporotic fractures (appendicular fractures).

3.4. Physical Activity and Exercise. Bone cross-sectional area is associated with muscle cross-sectional area [152], and lean mass correlates with areal BMD [153]. In addition, muscle volume and estimated torque of muscles have been suggested to explain differences in structural bone strength [154]. Consequently, the positive association between muscle and bone tissue has been suggested to be a result of the forces that muscles exert on the bones [155].

Inactivity is a well-demonstrated cause of significant loss of muscle mass and strength at all ages [156, 157]. Moreover, there are differences in effects of different types of physical activity with regards to response of muscle tissue. While aerobic exercise contributes less to muscle hypertrophy in comparison to resistance training, it has significant impact on protein synthesis, satellite cell activation, and increased muscle fiber area [158-160]. Aerobic exercise may also decrease the body fat infiltration of muscle tissue improving the functional properties of muscle system relative to body weight. Resistance training, however, significantly improves the muscle mass, strength, and their interaction in postmenopausal age group $[27,161]$. Interestingly, the effects of resistance training may have muscle-quality-improving effects even among the frail older population [162-168]. However, the amount of training, whether aerobic or resistance type in nature, may need intensity more than typical for leisure type of physical activity in order to have significant effects [169]. From the clinical viewpoint, an important facet of the effects of exercise on muscle tissue is that prevention of sarcopenia with exercise may not have sufficient power to occur at short period of time, especially among the elderly $[170,171]$. Consequently, it is widely accepted that prevention of sarcopenia should be carried out throughout the lifespan.

It has been postulated that both decreasing muscle activity and muscle mass are the main causes of bone loss during aging [172]. Furthermore, in experimental models, mature skeleton is less sensitive to exercise-induced peak muscle strain than growing bone [173]. In adult bone exercise most likely induces conservation rather than gains in strength [174]. According to previous studies, muscle strength, impact, and nonimpact exercise as well as the overall physical activity level are positively associated with 
BMD, bone loss rate, and fracture risk [5, 62, 144-177]. Analogously, immobilization has been demonstrated to accelerate bone loss rate [178]. Certain appendicular muscle strength measures, most importantly grip strength, have been demonstrated to correlate well with the overall muscle performance and strength [35, 179]. Grip strength may have diagnostic value for prediction of fractures [176] and selection of patients to BMD measurements [180]. It has been suggested, that in elderly women's lean mass correlates with BMD irrespective of body site but that the association between muscle strength and BMD is site-specific [62].

Functional capacity has been shown to be associated with higher BMD and predict fractures in postmenopausal women $[180,181]$. Kärkkäinen et al. found that standing on one foot (SOOF) less than 10 seconds increased the risk of hip fracture 9-fold, and self-assessed ability to walk less than $100 \mathrm{~m}$ increased the risk of clinical vertebral fractures 4fold and hip fracture 11-fold in postmenopausal population [181]. Moreover, a recent Cochrane review on the effects of exercise on preventing and treating postmenopausal osteoporosis concluded that especially weight-bearing exercise is effective in increasing BMD, although exercise seems not to prevent fractures during the first two years of therapy [182].

To conclude, muscle and bone strength are directly positively linked. Physical exercise has both muscle and bone tissue maintaining capabilities in postmenopausal women.

3.5. Vitamin D. There are two forms of vitamin D, ergocalciferol (vitamin D2) and cholecalciferol (vitamin D3). Cholecalciferol is the metabolically active form of vitamin D. Vitamin D is produced with either the effect of ultraviolet B radiation or ingested with nutrition, and the metabolically active form is produced in the kidneys.

Vitamin D receptor is present in skeletal muscle [183]. Vitamin D deficiency affects predominantly weight-bearing muscles of the lower limb $[184,185]$. Previous studies have shown that vitamin D levels are positively associated with muscle power, function, and physical performance [186, 187]. Doses of $400 \mathrm{IU}$ vitamin $\mathrm{D}$ may not be sufficient to improve muscle function in nondepleted population. Nevertheless, in vitamin-D-deficient subjects, vitamin D $400 \mathrm{IU}$, with calcium $800 \mathrm{mg}$, has been reported to improve gait speed and body sway [188]. In the age group of the postmenopausal population, vitamin D $800 \mathrm{IU}$ with calcium $1000 \mathrm{mg}$ has shown to improve muscle function $[189,190]$. Patients with low 25(OH)D levels have been shown to have impaired functional performance, psychomotor function, muscle strength and increased falling tendency [191, 192]. Previously, vitamin D has been reported to improve postural and dynamic balance [193]. Although it has been suggested that calcium supplementation is necessary for optimal action of vitamin D [194], combined vitamin D with calcium is superior to calcium alone in reducing the number of falls [190]. In the postmenopausal age group, low vitamin D and calcium intake and renal insufficiency may result in mild secondary hyperparathyroidism [195]. Indeed, low vitamin $\mathrm{D}$ and high parathyroid hormone levels have been found to increase the risk of low muscle mass and strength in postmenopausal population [195].
Vitamin D, combined to calcium, has been shown to decrease bone loss in adults and the elderly [196]. It has been postulated that serum $25(\mathrm{OH}) \mathrm{D}$ is a more important predictor of hip BMD than calcium intake [197], and correction of vitamin D hypovitaminosis has been demonstrated to result in increases in BMD [198]. Nevertheless, the protective effects of vitamin D have not been showed constantly [199], and, in postmenopausal women with adequate vitamin $\mathrm{D}$ levels, calcium supplementation may be as effective as vitamin D [200]. A recent Cochrane review on effects of vitamin $\mathrm{D}$ and vitamin $\mathrm{D}$ analogues on prevention fractures associated with involutional and postmenopausal osteoporosis concluded that vitamin $\mathrm{D}$ alone is unlike to prevent fractures while supplementation with calcium does appear to prevent fracture in institutional care [201].

To conclude, vitamin $D$ is essential in physiologicalprocesses-related muscle strength, function, and bone strength. Vitamin D substitution may prevent fractures and functional decline in postmenopausal women.

\section{Interactive Consequences of Osteoporosis and Sarcopenia: Falls and Frailty Syndrome}

4.1. Falls. An important common consequence of sarcopenia is tendency to fall which, together with osteoporosis, lead to fragility fractures. One-third of individuals aged 65 and older fall at least once each year, and about half of these fall twice or more $[202,203]$. Of these falls $3-6 \%$ lead to fractures [202, 204 ] typically distal radius, proximal humerus, and hip [205207]. Falls have complex and diverse causes. Maintenance of posture requires visual, tactile, proprioceptive, and vestibular competence, central processing, and coordinated motor response [208, 209]. Furthermore, ankle flexibility, plantar tactile sensation, and muscle strength have role in balance [210]. In addition, there are several comorbidities and medication that increase the risk of falling.

It has been shown that the upper and lower body weakness is adversely related to falls [211]. Lower extremity weakness is better predictor of falls than weakness of the upper body. Moreover, several single-intervention strategies for fall prevention have proven to be beneficial. Strength and balance training reduces both noninjurious and injurious falls [212-217]. However, multifactorial fall prevention has not been shown to have positive effect constantly $[218,219]$.

There are two main determinants for fragility fractures: bone material quality and tendency to fall. Vertebral fractures in the elderly population may occur without falls, while the incidence of other fractures is dependent on the tendency to fall. The most number of fragility fractures occur among women without osteoporotic BMD [220] although the risk of fracture is higher in women with low BMD. The risk of falling has been more closely related with limb fracture risk than BMD [221], and postmenopausal women with the highest physical activity level may have moderately higher wrist fracture incidence despite of lower bone loss rate [222].

To conclude, falls are more frequent in sarcopenic subjects and especially increase the functional decline among osteoporotic subjects. 


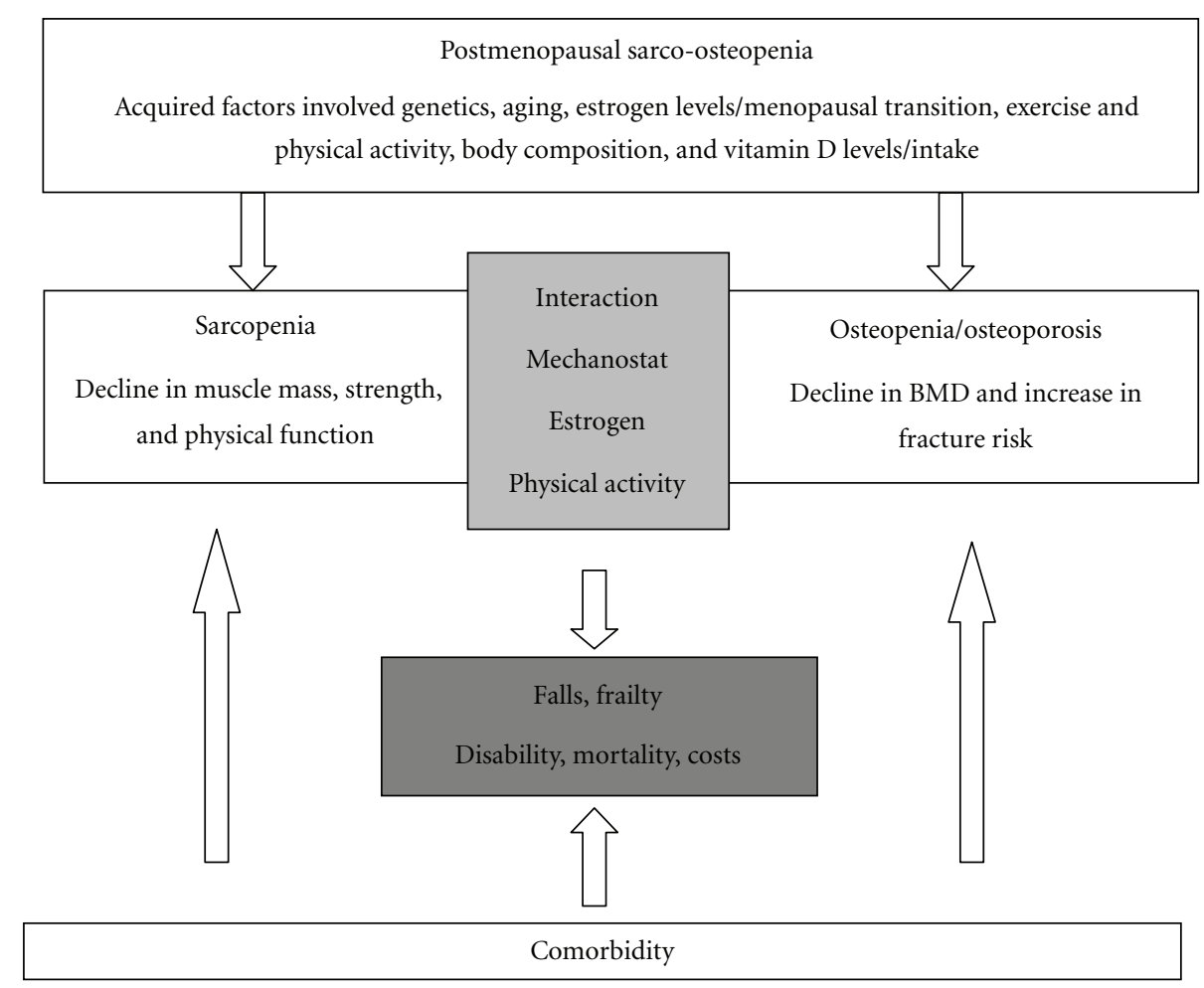

FIgURE 1: Dimensions of postmenopausal sarcopenia, osteoporosis, and frailty syndrome.

4.2. Frailty Syndrome. By definition, central element defining frailty is a state of great vulnerability of an aged subject when confronted by a stressor. Components of sarcopenia are substantially included into the concept of frailty among the elderly. Frailty syndrome has been defined as a clinical syndrome in which three or more of the following criteria are present: unintentional significant weight loss, self-reported exhaustion, weakness (measured with grip strength), slow walking speed, and low physical activity [223]. Given this frame, it has been postulated that sarcopenia and related poor muscle strength limits mobility and physical activity and thereby reduces total energy expenditure and nutritional intake, which, in turn, lead to weight loss and further aggravate sarcopenia [224]. Previous studies have indicated that the components of both sarcopenia and frailty syndrome are significant and independent risk factors of disability and death $[225,226]$. A recent study found a strong association between this commonly used definition for the frailty syndrome and lower extremity indexes of body composition [226]. Frail's older persons had lower muscle density and muscle mass and higher fat mass. Moreover, in an analysis of the single criterion composing the frailty score, physical inactivity was the strongest correlate of body composition. However, as with definition of sarcopenia, the uniform criteria for frailty syndrome have not fully developed and should be reassessed across populations. Furthermore, osteoporosis and bone fragility may be considered to further aggrevate the consequences of frailty syndrome. Presently, the criteria of frailty syndrome does not include assessment of osteoporosis or BMD. However, previous studies have shown associations between components of osteoporosis and frailty syndrome [227] and have been reviewed thoroughly recently [228]. Furthermore, a recent study by Frisoli et al. has demonstrated, that osteoporosis plus sarcopenia have concomitant impact on frailty status in elderly women [229]. It was found that, in the presence of both sarcopenia and osteoporosis, the odds for frailty were over two times higher (OR 6.4) than those in presence of either syndrome alone (OR 3.1 for sarcopenia and OR 2.1 for osteoporosis). It must be reminded, however, that clinically significant frailty generally occurs decades after the menopausal transition itself.

To conclude, frailty syndrome presents the most aggravated form of increased morbidity among sarcopenic plus osteoporotic subjects.

\section{Conclusions}

Figure 1 summarizes the associations between postmenopausal osteoporosis, sarcopenia, falls, and frailty syndrome.

Postmenopausal women are at risk of both osteoporosis and sarcopenia. There is evidence that these two conditions coexists and share similar risk factors. Both sarcopenia and osteoporosis are strongly linked not only to aging but also to estrogen depletion and thereby to menopausal transition. This makes the postmenopausal population a significant target group for prevention of both sarcopenia and osteoporosis.

While the associations between muscle strength, muscle mass, and functional capacity with clinically relevant endpoint of osteoporosis, that is, BMD and fractures, have been 
reported, there are no studies addressing the associations between three stages of clinical sarcopenia, that is, presarcopenia, sarcopenia, and severe sarcopenia. The associations of the three modalities of sarcopenia with osteopenia, osteoporosis, and severe osteoporosis remain unexplored. An essential part of the diagnosis of both osteoporosis and sarcopenia includes DXA, which allows simultaneous assessment of both conditions. The future research should concentrate on exploring the clinically relevant dimensions and interactions of sarcopenia and osteoporosis.

\section{Acknowledgment}

The present work has received financial support from the Kuopio University Hospital EVO Grant.

\section{References}

[1] The World Health Report, "Making a difference," 1999, http://www.who.int/whr/1999/en/index.html.

[2] A. Oksuzyan, K. Juel, J. W. Vaupel, and K. Christensen, "Men: good health and high mortality. Sex differences in health and aging," Aging Clinical and Experimental Research, vol. 20, no. 2, pp. 91-102, 2008.

[3] A. Case and C. Paxson, "Sex differences in morbidity and mortality," Demography, vol. 42, no. 2, pp. 189-214, 2005.

[4] H. G. Burger, G. E. Hale, D. M. Robertson, and L. Dennerstein, "A review of hormonal changes during the menopausal transition: focus on findings from the Melbourne Women's Midlife Health Project," Human Reproduction Update, vol. 13, no. 6, pp. 559-565, 2007.

[5] L. R. Nelson and S. E. Bulun, "Estrogen production and action," Journal of the American Academy of Dermatology, vol. 45, no. 3, pp. S116-S124, 2001.

[6] S. R. Cummings and L. J. Melton, "Osteoporosis I: epidemiology and outcomes of osteoporotic fractures," Lancet, vol. 359, no. 9319, pp. 1761-1767, 2002.

[7] S. Palacios, R. S. Borrego, and A. Forteza, "The importance of preventive health care in post-menopausal women," Maturitas, vol. 52, no. 1, supplement, pp. S53-S60, 2005.

[8] G. Abellan Van Kan, "Epidemiology and consequences of sarcopenia," Journal of Nutrition, Health and Aging, vol. 13, no. 8, pp. 708-712, 2009.

[9] L. J. Melton III, E. A. Chrischilles, C. Cooper, A. W. Lane, and B. L. Riggs, "Perspective: how many women have osteoporosis?" Journal of Bone and Mineral Research, vol. 7, no. 9, pp. 1005-1010, 1992.

[10] I. H. Rosenberg and R. Roubenoff, "Stalking sarcopenia," Annals of Internal Medicine, vol. 123, no. 9, pp. 727-728, 1995.

[11] R. N. Baumgartner, K. M. Koehler, D. Gallagher et al., "Epidemiology of sarcopenia among the elderly in New Mexico," American Journal of Epidemiology, vol. 147, no. 8, pp. 755-763, 1998.

[12] I. Janssen, R. N. Baumgartner, R. Ross, I. H. Rosenberg, and R. Roubenoff, "Skeletal muscle cutpoints associated with elevated physical disability risk in older men and women," American Journal of Epidemiology, vol. 159, no. 4, pp. 413$421,2004$.

[13] L. J. Melton III, S. Khosla, C. S. Crowson, M. K. O'Connor, W. M. O'Fallon, and B. L. Riggs, "Epidemiology of sarcopenia," Journal of the American Geriatrics Society, vol. 48, no. 6, pp. 625-630, 2000.
[14] I. Janssen, S. B. Heymsfield, and R. Ross, "Low relative skeletal muscle mass (sarcopenia) in older persons is associated with functional impairment and physical disability," Journal of the American Geriatrics Society, vol. 50, no. 5, pp. 889-896, 2002.

[15] J. Sirola, M. Tuppurainen, T. Rikkonen, R. Honkanen, H. Koivumaa-Honkanen, and H. Kröger, "Correlates and predictors of self-rated health and ambulatory status among elderly women-cross-sectional and 10 years populationbased cohort study," Maturitas, vol. 65, no. 3, pp. 244-252, 2010.

[16] I. Janssen, D. S. Shepard, P. T. Katzmarzyk, and R. Roubenoff, "The healthcare costs of sarcopenia in the United States," Journal of the American Geriatrics Society, vol. 52, no. 1, pp. 80-85, 2004.

[17] N. F. Ray, J. K. Chan, M. Thamer, and L. J. Melton, "Medical expenditures for the treatment of osteoporotic fractures in the United States in 1995. Report from the National Osteoporosis Foundation," Journal of Bone and Mineral Research, vol. 12, no. 1, pp. 24-35, 1997.

[18] E. Dennison, Z. Cole, and C. Cooper, "Diagnosis and epidemiology of osteoporosis," Current Opinion in Rheumatology, vol. 17, no. 4, pp. 456-461, 2005.

[19] S. R. Cummings and L. J. Melton, "Epidemiology and outcomes of osteoporotic fractures," Lancet, vol. 359, no. 9319, pp. 1761-1767, 2002.

[20] A. J. Cruz-Jentoft, J. P. Baeyens, J. M. Bauer et al., "Sarcopenia: European consensus on definition and diagnosis Report of the European Working Group on Sarcopenia in older people," Age and Ageing, vol. 39, pp. 412-423, 2010.

[21] R. N. Baumgartner and D. L. Waters, "Sarcopenia and sarcopenic obesity," in Principles and Practice of Geriatric Meidcine, M. S. J. Pathy, Ed., pp. 909-933, John Wiley and Sons, London, UK, 2006.

[22] T. Lang, T. Steeper, P. Cawthon, K. Baldwin, D. R. Taafe, and T. B. Harris, "Sarcopenia: etiology, clinical consequences, intervention and assessement," Osteoporosis International, vol. 21, pp. 543-559, 2010.

[23] B. H. Goodpaster, S. W. Park, T. B. Harris et al., "The loss of skeletal muscle strength, mass, and quality in older adults. The Health, Aging and Body Composition Study," Journal of Gerontology Series A, vol. 61, no. 10, pp. 1059-1064, 2006.

[24] T. J. Doherty, "Invited review: aging and sarcpenia," Journal of Applied Physiology, vol. 95, pp. 140-145, 2003.

[25] B. C. Clark and T. M. Manini, "Sarcopenia $\neq$ dynapenia," Journals of Gerontology Series A, vol. 63, no. 8, pp. 829-834, 2008.

[26] M. J. Delmonico, T. B. Harris, J. S. Lee et al., "Alternative definitions of sarcopenia, lower extremity performance, and functional impairment with aging in older men and women," Journal of the American Geriatrics Society, vol. 55, no. 5, pp. 769-774, 2007.

[27] Y. Rolland, S. Czerwinski, G. A. Van Kan et al., "Sarcopenia: its assessment, etiology, pathogenesis, consequences and future perspectives," Journal of Nutrition, Health and Aging, vol. 12, no. 7, pp. 433-450, 2008.

[28] I. Janssen, S. B. Heymsfield, R. N. Baumgartner, and R. Ross, "Estimation of skeletal muscle mass by bioelectrical impedance analysis," Journal of Applied Physiology, vol. 89, no. 2, pp. 465-471, 2000.

[29] U. G. Kyle, L. Genton, D. O. Slosman, and C. Pichard, "Fatfree and fat mass percentiles in 5225 healthy subjects aged 15 to 98 years," Nutrition, vol. 17, no. 7-8, pp. 534-541, 2001. 
[30] R. Roubenoff, R. N. Baumgartner, T. B. Harris et al., "Application of bioelectrical impedance analysis to elderly populations," Journals of Gerontology Series A, vol. 52, no. 3, pp. M129-M136, 1997.

[31] U. G. Kyle, L. Genton, L. Karsegard, D. O. Slosman, and C. Pichard, "Single prediction equation for bioelectrical impedance analysis in adults aged 20-94 years," Nutrition, vol. 17, no. 3, pp. 248-253, 2001.

[32] M. Y. Chien, T. Y. Huang, and Y. T. Wu, "Prevalence of sarcopenia estimated using a bioelectrical impedance analysis prediction equation in community-dwelling elderly people in Taiwan," Journal of the American Geriatrics Society, vol. 56, no. 9, pp. 1710-1715, 2008.

[33] M. Visser, B. H. Goodpaster, S. B. Kritchevsky et al., "Muscle mass, muscle strength, and muscle fat infiltration as predictors of incident mobility limitations in well-functioning older persons," Journals of Gerontology Series A, vol. 60, no. 3, pp. 324-333, 2005.

[34] Y. Rolland, V. Lauwers-Cances, M. Cournot et al., "Sarcopenia, calf circumference, and physical function of elderly women: a cross-sectional study," Journal of the American Geriatrics Society, vol. 51, no. 8, pp. 1120-1124, 2003.

[35] J. Sirola, T. Rikkonen, H. Kröger et al., "Factors related to postmenopausal muscle performance: a cross-sectional population-based study," European Journal of Applied Physiology, vol. 93, no. 1-2, pp. 102-107, 2004.

[36] S. Al Snih, K. S. Markides, K. J. Ottenbacher, and M. A. Raji, "Hand grip strength and incident ADL disability in elderly Mexican Americans over a seven-year period," Aging Clinical and Experimental Research, vol. 16, no. 6, pp. 481-486, 2004.

[37] T. Rantanen, S. Volpato, L. Ferrucci, E. Heikkinen, L. P. Fried, and J. M. Guralnik, "Handgrip strength and cause-specific and total mortality in older disabled women: exploring the mechanism," Journal of the American Geriatrics Society, vol. 51, no. 5, pp. 636-641, 2003.

[38] M. Brown, D. R. Sinacore, E. F. Binder, and W. M. Kohrt, "Physical and performance measures for the identification of mild to moderate frailty," Journals of Gerontology Series A, vol. 55, no. 6, pp. M350-M355, 2000.

[39] D. Callahan, E. Phillips, R. Carabello, W. R. Frontera, and R. A. Fielding, "Assessment of lower extremity muscle power in functionally-limited elders," Aging Clinical and Experimental Research, vol. 19, no. 3, pp. 194-199, 2007.

[40] J. A. Neder, L. E. Nery, G. T. Shinzato, M. S. Andrade, C. Peres, and A. C. Silva, "Reference values for concentric knee isokinetic strength and power in nonathletic men and women from 20 to 80 years old," Journal of Orthopaedic and Sports Physical Therapy, vol. 29, no. 2, pp. 116-126, 1999.

[41] B. H. Goodpaster, C. L. Carlson, M. Visser et al., "Attenuation of skeletal muscle and strength in the elderly: the health ABC study," Journal of Applied Physiology, vol. 90, no. 6, pp. 2157 2165, 2001.

[42] A. B. Newman, C. L. Haggerty, B. Goodpaster et al., "Strength and muscle quality in a well-functioning cohort of older adults. The Health, Aging and Body Composition Study," Journal of the American Geriatrics Society, vol. 51, no. 3, pp. 323-330, 2003.

[43] W. J. Evans, S. Bhasin, E. Cress et al., "Functional outcomes for clinical trials in frail older persons: time to be moving," Journals of Gerontology Series A, vol. 63, no. 2, pp. 160-164, 2008.

[44] J. M. Guralnik, E. M. Simonsick, L. Ferrucci et al., "A short physical performance battery assessing lower extremity function: association with self-reported disability and prediction of mortality and nursing home admission," Journals of Gerontology, vol. 49, no. 2, pp. M85-M94, 1994.

[45] S. Mathias, U. S. L. Nayak, and B. Isaacs, "Balance in elderly patients: the "get-up and go" test," Archives of Physical Medicine and Rehabilitation, vol. 67, no. 6, pp. 387-389, 1986.

[46] J. F. Bean, D. K. Kiely, S. LaRose, J. Alian, and W. R. Frontera, "Is stair climb power a clinically relevant measure of leg power impairments in at-risk older adults?" Archives of Physical Medicine and Rehabilitation, vol. 88, no. 5, pp. 604609, 2007.

[47] NIH, "Osteoporosis. NIH consensus development conference consensus statement," US Department of Health and Human Services, National Institutes of Health, vol. 5, no. 3, pp. 1-6, 1984.

[48] S. R. Cummings, D. M. Black, M. C. Nevitt et al., "Bone density at various sites for prediction of hip fractures," Lancet, vol. 341, no. 8837, pp. 72-75, 1993.

[49] H. Kröger, J. Huopio, R. Honkanen et al., "Prediction of fracture risk using axial bone mineral density in a perimenopausal population: a prospective study," Journal of Bone and Mineral Research, vol. 10, no. 2, pp. 302-306, 1995.

[50] R. Honkanen, H. Kröger, M. Tuppurainen, E. Alhava, and S. Saarikoski, "Fractures and low axial bone density in perimenopausal women," Journal of Clinical Epidemiology, vol. 48, no. 7, pp. 881-888, 1995.

[51] J. Huopio, H. Kröger, R. Honkanen, S. Saarikoski, and E. Alhava, "Risk factors for perimenopausal fractures: a prospective study," Osteoporosis International, vol. 11, no. 3, pp. 219-227, 2000.

[52] B. J. Riis, M. A. Hansen, A. M. Jensen, K. Overgaard, and C. Christiansen, "Low bone mass and fast rate of bone loss at menopause: equal risk factors for future fracture: a 15-year follow-up study," Bone, vol. 19, no. 1, pp. 9-12, 1996.

[53] M. A. Hansen, K. Overgaard, B. J. Riis, and C. Christiansen, "Role of peak bone mass and bone loss in postmenopausal osteoporosis: 12 year study," British Medical Journal, vol. 303, no. 6808, pp. 961-964, 1991.

[54] K. E. Ensrud, L. Palermo, D. M. Black et al., "Hip and calcaneal bone loss increase with advancing age: longitudinal results from the study of osteoporotic fractures," Journal of Bone and Mineral Research, vol. 10, no. 11, pp. 1778-1787, 1995.

[55] "Osteoporosis: review of the evidence for prevention, diagnosis and treatment and costeffectiveness analysis (1998) Status report developed by the National Osteoporosis Foundation," Osteoporosis International, vol. 8, supplement 4, 1998.

[56] J. A. Kanis, O. Johnell, A. Oden, H. Johansson, and E. McCloskey, "FRAX ${ }^{\mathrm{TM}}$ and the assessment of fracture probability in men and women from the UK," Osteoporosis International, vol. 19, no. 4, pp. 385-397, 2008.

[57] S. R. Cummings, M. C. Nevitt, W. S. Browner et al., "Risk factors for hip fracture in white women," New England Journal of Medicine, vol. 332, no. 12, pp. 767-773, 1995.

[58] "NIH Consensus Developement Palnel on Osteoporosis Prevention," Journal of the American Medical Association, vol. 14, no. 285, pp. 785-795, 2001.

[59] D. Karasik and D. P. Kiel, "Genetics of the musculoskeletal system: a pleiotropic approach," Journal of Bone and Mineral Research, vol. 23, no. 6, pp. 788-802, 2008.

[60] T. Douchi, T. Oki, S. Nakamura, H. Ijuin, S. Yamamoto, and Y. Nagata, "The effect of body composition on bone density in pre- and postmenopausal women," Maturitas, vol. 27, no. 1, pp. 55-60, 1997. 
[61] M. Visser, D. P. Kiel, J. Lagois et al., "Muscle mass and fat mass in relation to bone mireal density in very old men and women. The Framingham Heart Study," Applied Radiation and Isotopes, vol. 49, pp. 745-747, 1998.

[62] H. Blain, A. Vuillemin, A. Teissier, B. Hanesse, F. Guillemin, and C. Jeandel, "Influence of muscle strength and body weight and composition on regional bone mineral density in healthy women aged 60 years and over," Gerontology, vol. 47, no. 4, pp. 207-212, 2001.

[63] M. C. Walsh, G. R. Hunter, and M. B. Livingstone, "Sarcopenia in premenopausal and postmenopausal women with osteopenia, osteoporosis and normal bone mineral density," Osteoporosis International, vol. 17, no. 1, pp. 61-67, 2006.

[64] S. Gillette-Guyonnet, F. Nourhashemi, S. Lauque, H. Grandjean, and B. Vellas, "Body composition and osteoporosis in elderly women,” Gerontology, vol. 46, no. 4, pp. 189-193, 2000.

[65] H. M. Frost, "Bone "mass" and the "mechanostat": a proposal," Anatomical Record, vol. 219, no. 1, pp. 1-9, 1987.

[66] O. M. Pearson and D. E. Lieberman, "The aging of Wolff's "law": ontogeny and responses to mechanical loading in cortical bone," American Journal of Physical Anthropology, vol. 39, pp. 63-99, 2004.

[67] T. Matsuoka, P. E. Ahlberg, N. Kessaris et al., "Neural crest origins of the neck and shoulder," Nature, vol. 436, no. 7049, pp. 347-355, 2005.

[68] S. E. Churchill, "Particulate versus integrated evolution of the upper body in late pleistocene humans: a test of two models," American Journal of Physical Anthropology, vol. 100, no. 4, pp. 559-583, 1996.

[69] D. Karasik and D. P. Kiel, "Evidence for pleiotropic factors in genetics of the musculoskeletal system," Bone, vol. 46, no. 5, pp. 1226-1237, 2010.

[70] V. Gilsanz, T. A. L. Wren, M. Sanchez, F. Dorey, S. Judex, and C. Rubin, "Low-level, high-frequency mechanical signals enhance musculoskeletal development of young women with low BMD," Journal of Bone and Mineral Research, vol. 21, no. 9, pp. 1464-1474, 2006.

[71] F. Lauretani, S. Bandinelli, B. Bartali et al., "Axonal degeneration affects muscle density in older men and women," Neurobiology of Aging, vol. 27, no. 8, pp. 1145-1154, 2006.

[72] A. M. Qureshi, F. E. A. McGuigan, D. G. Seymour, J. D. Hutchison, D. M. Reid, and S. H. Ralston, "Association between COLIA1 Sp1 alleles and femoral neck geometry," Calcified Tissue International, vol. 69, no. 2, pp. 67-72, 2001.

[73] F. Rivadeneira, J. J. Houwing-Duistermaat, T. J. Beck et al., "The influence of an insulin-like growth factor I gene promoter polymorphism on hip bone geometry and the risk of nonvertebral fracture in the elderly. The Rotterdam study," Journal of Bone and Mineral Research, vol. 19, no. 8, pp. 1280 1290, 2004.

[74] J. B. J. Van Meurs, F. Rivadeneira, M. Jhamai et al., "Common genetic variation of the low-density lipoprotein receptorrelated protein 5 and 6 genes determines fracture risk in elderly white men," Journal of Bone and Mineral Research, vol. 21, no. 1, pp. 141-150, 2006.

[75] M. J. Khoury, L. L. McCabe, and E. R. B. McCabe, "Population screening in the age of genomic medicine," New England Journal of Medicine, vol. 348, no. 1, pp. 50-58, 2003.

[76] K. Tiainen, S. Sipilä, M. Alén et al., "Shared genetic and environmental effects on strength and power in older female twins," Medicine and Science in Sports and Exercise, vol. 37, no. 1, pp. 72-78, 2005.
[77] K. M. Tiainen, M. Perola, V. M. Kovanen et al., "Genetics of maximal walking speed and skeletal muscle characteristics in older women," Twin Research and Human Genetics, vol. 11, no. 3, pp. 321-334, 2008.

[78] H. Xu, J. R. Long, Y. J. Yang, F. Y. Deng, and H. W. Deng, "Genetic determination and correlation of body weight and body mass index (BMI) and cross-sectional geometric parameters of the femoral neck," Osteoporosis International, vol. 17, no. 11, pp. 1602-1607, 2006.

[79] E. Seeman, J. L. Hopper, N. R. Young, C. Formica, P. Goss, and C. Tsalamandris, "Do genetic factors explain associations between muscle strength, lean mass, and bone density? A twin study," American Journal of Physiology, vol. 270, no. 2, pp. E320-E327, 1996.

[80] T. M. Mikkola, S. Sipilä, T. Rantanen et al., "Muscle crosssectional area and structural bone strength share genetic and environmental effects in older women," Journal of Bone and Mineral Research, vol. 24, no. 2, pp. 338-345, 2009.

[81] L. Larsson, G. Grimby, and J. Karlsson, "Muscle strength and speed of movement in relation to age and muscle morphology," Journal of Applied Physiology Respiratory Environmental and Exercise Physiology, vol. 46, no. 3, pp. 451-456, 1979.

[82] G. Grimby and B. Saltin, "Mini-review: the aging muscle," Clinical Physiology, vol. 3, no. 3, pp. 209-218, 1983.

[83] V. A. Hughes, W. R. Frontera, R. Roubenoff, W. J. Evans, and M. A. Fiatarone Singh, "Longitudinal changes in body composition in older men and women: role of body weight change and physical activity," American Journal of Clinical Nutrition, vol. 76, no. 2, pp. 473-481, 2002.

[84] A. A. Vandervoort, "Aging of the human neuromuscular system," Muscle and Nerve, vol. 25, no. 1, pp. 17-25, 2002.

[85] R. Roubenoff and V. A. Hughes, "Sarcopenia: current concepts," Journals of Gerontology Series A, vol. 55, no. 12, pp. M716-M724, 2000.

[86] J. E. Morley et al., "Sarcopenia," Journal of Laboratory and Clinical Medicine, vol. 137, pp. 231-243, 2001.

[87] W. Evans, "Functional and metabolic consequences of sarcopenia," Journal of Nutrition, vol. 127, no. 5, pp. 998S1003S, 1997.

[88] M. M. Samson, I. B. A. E. Meeuwsen, A. Crowe, J. A. G. Dessens, S. A. Duursma, and H. J. J. Verhaar, "Relationships between physical performance measures, age, height and body weight in healthy adults," Age and Ageing, vol. 29, no. 3, pp. 235-242, 2000.

[89] S. K. Phillips, K. M. Rook, N. C. Siddle, S. A. Bruce, and R. C. Woledge, "Muscle weakness in women occurs at an earlier age than in men, but strength is preserved by hormone replacement therapy," Clinical Science, vol. 84, no. 1, pp. 9598, 1993.

[90] T. Douchi, S. Yamamoto, S. Nakamura et al., "The effect of menopause on regional and total body lean mass," Maturitas, vol. 29, no. 3, pp. 247-252, 1998.

[91] V. Messier, R. Rabasa-Lhoret, S. Barbat-Artigas, B. Elisha, A. D. Karelis, and M. Aubertin-Leheurde, "Menopause and sarcopenia: apotential role for sex hormones," Maturitas, vol. 68, pp. 331-336, 2011.

[92] M. Iannuzzi-Sucich, K. M. Prestwood, and A. M. Kenny, "Prevalence of sarcopenia and predictors of skeletal muscle mass in healthy, older men and women," Journals of Gerontology Series A, vol. 57, no. 12, pp. M772-M777, 2002.

[93] M. Brown, "Skeletal muscle and bone: effect of sex steroids and aging," American Journal of Physiology, vol. 32, no. 2, pp. 120-126, 2008. 
[94] R. Roubenoff, "Catabolism of aging: is it an inflammatory process?" Current Opinion in Clinical Nutrition and Metabolic Care, vol. 6, no. 3, pp. 295-299, 2003.

[95] J. P. Greeves, N. T. Cable, T. Reilly, and C. Kingsland, "Changes in muscle strength in women following the menopause: a longitudinal assessment of the efficacy of hormone replacement therapy," Clinical Science, vol. 97, no. 1, pp. 79-84, 1999.

[96] S. Sipilä, D. R. Taaffe, S. Cheng, J. Puolakka, J. Toivanen, and H. Suominen, "Effects of hormone replacement therapy and high-impact physical exercise on skeletal muscle in post-menopausal women: a randomized placebo-controlled study," Clinical Science, vol. 101, no. 2, pp. 147-157, 2001.

[97] M. B. Sørensen, A. M. Rosenfalck, L. Højgaard, and B. Ottesen, "Obesity and sarcopenia after menopause are reversed by sex hormone replacement therapy," Obesity Research, vol. 9, no. 10, pp. 622-626, 2001.

[98] Z. Chen, T. Bassford, S. B. Green et al., "Postmenopausal hormone therapy and body composition - A substudy of the estrogen plus progestin trial of the Women's Health Initiative," American Journal of Clinical Nutrition, vol. 82, no. 3, pp. 651-656, 2005.

[99] R. D. Hansen, C. Raja, R. J. Baber, D. Lieberman, and B. J. Allen, "Effects of 20-mg oestradiol implant therapy on bone mineral density, fat distribution and muscle mass in postmenopausal women," Acta Diabetologica, vol. 40, no. 1, pp. S191-S195, 2003.

[100] A. M. Kenny, L. Dawson, A. Kleppinger, M. Iannuzzi-Sucich, and J. O. Judge, "Prevalence of sarcopenia and predictors of skeletal muscle mass in nonobese women who are longterm users of estrogen-replacement therapy," Journals of Gerontology Series A, vol. 58, no. 5, pp. 436-440, 2003.

[101] M. J. Ousler, M. Kassem, R. Turner, B. L. Riggs, and T. C. Spelsberg, "Regulation of bone cell function by gonadal steroids," in Osteoprosis, R. Marcus, D. Feldman, and J. Kelsey, Eds., pp. 237-253, Academic Press, San Diego, Calif, USA, 1996.

[102] S. C. Manolagas, "The role of IL-6 type cytokines and their receptors in bone a," Annals of the New York Academy of Sciences, vol. 840, pp. 194-204, 1998.

[103] B. L. Riggs, S. Khosla, and L. J. Melton III, "Sex steroids and the construction and conservation of the adult skeleton," Endocrine Reviews, vol. 23, no. 3, pp. 279-302, 2002.

[104] S. Adami, D. Gatti, F. Bertoldo et al., "The effects of menopause and estrogen replacement therapy on the renal handling of calcium," Osteoporosis International, vol. 2, no. 4, pp. $180-185,1992$.

[105] J. M. Pouilles, F. Tremollieres, and C. Ribot, "The effects of menopause on longitudinal bone loss from the spine," Calcified Tissue International, vol. 52, no. 5, pp. 340-343, 1993.

[106] J. M. Pouilles, F. Tremollieres, and C. Ribot, "Effect of menopause on femoral and vertebral bone loss," Journal of Bone and Mineral Research, vol. 10, no. 10, pp. 1531-1536, 1995.

[107] M. Tuppurainen, R. Honkanen, H. Kröger, S. Saarikoski, and E. Alhava, "Osteoporosis risk factors, gynaecological history and fractures in perimenopausal women - the results of the baseline postal enquiry of the Kuopio Osteoporosis Risk Factor and Prevention Study," Maturitas, vol. 17, no. 2, pp. 89-100, 1993.

[108] H. Kröger, M. Tuppurainen, R. Honkanen, E. Alhava, and S. Saarikoski, "Bone mineral density and risk factors for osteoporosis - a population-based study of 1600 perimenopausal women," Calcified Tissue International, vol. 55, no. 1, pp. 1-7, 1994.

[109] H. G. Ahlborg, O. Johnell, B. E. Nilsson, S. Jeppsson, G. Rannevik, and M. K. Karlsson, "Bone loss in relation to menopause: a prospective study during 16 years," Bone, vol. 28, no. 3, pp. 327-331, 2001.

[110] J. C. Prior, "Perimenopause: the complex endocrinology of the menopausal transition," Endocrine Reviews, vol. 19, no. 4, pp. 397-428, 1998.

[111] S. Harris and B. Dawson-Hughes, "Rates of change in bone mineral density of the spine, heel, femoral neck and radius in healthy postmenopausal women," Bone and Mineral, vol. 17, no. 1, pp. 87-95, 1992.

[112] M. A. Hansen, K. Overgaard, and C. Christiansen, "Spontaneous postmenopausal bone loss in different skeletal areasfollowed up for 15 years," Journal of Bone and Mineral Research, vol. 10, no. 2, pp. 205-210, 1995.

[113] R. Young, H. May, S. Murphy, C. Grey, and J. E. Compston, "Rates of bone loss in peri- and postmenopausal women: a 41 year, prospective, population-based study," Clinical Science, vol. 91, no. 3, pp. 307-312, 1996.

[114] M. Ito, T. Nakamura, K. Tsurusaki, M. Uetani, and K. Hayashi, "Effects of menopause on age-dependent bone loss in the axial and appendicular skeletons in healthy Japanese women," Osteoporosis International, vol. 10, no. 5, pp. 377383, 1999.

[115] J. A. Pasco, E. Seeman, M. J. Henry, E. N. Merriman, G. C. Nicholson, and M. A. Kotowicz, "The population burden of fractures originates in women with osteopenia, not osteoporosis," Osteoporosis International, vol. 17, no. 9, pp. 1404-1409, 2006.

[116] R. Lindsay and J. F. Tohme, "Estrogen treatment of patients with established postmenopausal osteoporosis," Obstetrics and Gynecology, vol. 76, no. 2, pp. 290-295, 1990.

[117] J. A. Cauley, D. G. Seeley, K. Ensrud, B. Ettinger, D. Black, and S. R. Cummings, "Estrogen replacement therapy and fractures in older women," Annals of Internal Medicine, vol. 122, no. 1, pp. 9-16, 1995.

[118] D. L. Schneider, E. L. Barrett-Connor, and D. J. Morton, "Timing of postmenopausal estrogen for optimal bone mineral density. The Rancho Bernardo study," Journal of the American Medical Association, vol. 277, no. 7, pp. 543-547, 1997.

[119] M. H. Komulainen, H. Kröger, M. T. Tuppurainen et al., "HRT and Vit D in prevention of non-vertebral fractures in postmenopausal women; a 5 year randomized trial," Maturitas, vol. 31, no. 1, pp. 45-54, 1998.

[120] D. M. Eddy, C. C. Johnston Jr., S. R. Cummings et al., “Osteoporosis: review of the evidence for prevention, diagnosis, and treatment and cost-effectiveness analysis. Status report," Osteoporosis International, vol. 8, no. supplement 4, pp. S1S82, 1998.

[121] G. Wells, P. Tugwell, B. Shea et al., "V. Meta-analysis of the efficacy of hormone replacement therapy in treating and preventing osteoporosis in postmenopausal women," Endocrine Reviews, vol. 23, no. 4, pp. 529-539, 2002.

[122] C. R. Russo, M. Ricca, and L. Ferrucci, "True osteoporosis and frailty-related osteopenia: two different clinical entities," Journal of the American Geriatrics Society, vol. 48, no. 12, pp. 1738-1739, 2000.

[123] S. Maggi, F. Lauretani, L. Ferrucci et al., "The quality of bone: a "magic natural alloy"', Aging Clinical and Experimental Research, vol. 16, no. 3, pp. 3-9, 2004. 
[124] G. L. Jones and A. Sutton, "Quality of life in obese postmenopausal women," Menopause International, vol. 14, no. 1, pp. 26-32, 2008.

[125] K. E. Dennis, "Postmenopausal women and the health consequences of obesity," Journal of Obstetric, Gynecologic, and Neonatal Nursing, vol. 36, no. 5, pp. 511-519, 2007.

[126] C. E. I. Lebrun, Y. T. Van Der Schouw, F. H. De Jong, D. E. Grobbee, and S. W. Lamberts, "Fat mass rather than muscle strength is the major determinant of physical function and disability in postmenopausal women younger than 75 years of age," Menopause, vol. 13, no. 3, pp. 474-481, 2006.

[127] H. B. Hubert, D. A. Bloch, and J. F. Fries, "Risk factors for physical disability in an aging cohort. The NHANES I Epidemiologic Followup Study," Journal of Rheumatology, vol. 20, pp. 480-488, 1993.

[128] J. W. Davis, P. D. Ross, S. D. Preston, M. C. Nevitt, and R. D. Wasnich, "Strength, physical activity, and body mass index: relationship to performance-based measures and activities of daily living among older Japanese women in Hawaii," Journal of the American Geriatrics Society, vol. 46, no. 3, pp. 274-279, 1998.

[129] M. Visser, J. Langlois, J. M. Guralnik et al., "High body fatness, but not low fat-free mass, predicts disability in older men and women: the cardiovascular health study," American Journal of Clinical Nutrition, vol. 68, no. 3, pp. 584-590, 1998.

[130] A. Rissanen, M. Heliovaara, P. Knekt, A. Reunanen, A. Aromaa, and J. Maatela, "Risk of disability and mortality due to overweight in a Finnish population," British Medical Journal, vol. 301, no. 6756, pp. 835-837, 1990.

[131] N. Duvigneaud, L. Matton, K. Wijndaele et al., "Relationship of obesity with physical activity, aerobic fitness and muscle strength in Flemish adults," Journal of Sports Medicine and Physical Fitness, vol. 48, no. 2, pp. 201-210, 2008.

[132] M. Cesari, S. B. Kritchevsky, R. N. Baumgartner et al., "Sarcopenia, obesity, and inflammation-results from the Trial of Angiotensin Converting Enzyme Inhibition and Novel Cardiovascular Risk Factors study," American Journal of Clinical Nutrition, vol. 82, no. 2, pp. 428-434, 2005.

[133] B. H. Goodpaster, S. Krishnaswami, H. Resnick et al., "Association between regional adipose tissue distribution and both type 2 diabetes and impaired glucose tolerance in elderly men and women," Diabetes Care, vol. 26, no. 2, pp. 372-379, 2003.

[134] B. H. Goodpaster, S. Krishnaswami, H. Resnick et al., "Thigh adipose tissue distribution id associated with insuloin resistance in obesity and type 2 diabetes mellitus," The American Journal of Clinical Nutrition, vol. 71, pp. 885-892, 2000.

[135] D. L. Waters, C. R. Qualls, R. I. Dorin et al., "Altered growth hormone, cortical and leptin secretion in healthy elderly persons with sarcopenia and mixed body composition phenotyoes," Journals of Gerontology Series A, vol. 63, pp. 536-541, 2008.

[136] R. N. Baumgartner, "Body composition in healthy aging," Annals of the New York Academy of Sciences, vol. 904, pp. 437$448,2000$.

[137] M. Zamboni, G. Mazzali, F. Fantin, A. Rossi, and V. Di Francesco, "Sarcopenic obesity: a new category of obesity in the elderly," Nutrition, Metabolism and Cardiovascular Diseases, vol. 18, no. 5, pp. 388-395, 2008.

[138] E. Zoico, V. Di Francesco, J. M. Guralnik et al., "Physical disability and muscular strength in relation to obesity and different body composition indexes in a sample of healthy elderly women," International Journal of Obesity, vol. 28, no. 2, pp. 234-241, 2004.

[139] R. N. Baumgartner, S. J. Wayne, D. L. Waters, I. Janssen, D. Gallagher, and J. E. Morley, "Sarcopenic obesity predicts instrumental activities of daily living disability in the elderly," Obesity Research, vol. 12, no. 12, pp. 1995-2004, 2004.

[140] A. B. Newman, J. S. Lee, M. Visser et al., "Weight change and the conservation of lean mass in old age. The Health, Aging and Body Composition Study," American Journal of Clinical Nutrition, vol. 82, no. 4, pp. 872-878, 2005.

[141] T. N. Frimel, D. R. Sinacore, and D. T. Villareal, "Exercise attenuates the weight-loss-induced reduction in muscle mass in frail obese older adults," Medicine and Science in Sports and Exercise, vol. 40, no. 7, pp. 1213-1219, 2008.

[142] J. Sirola, T. Rikkonen, M. Tuppurainen, R. Honkanen, J. S. Jurvelin, and H. Kröger, "Maintenance of muscle strength may counteract weight-loss-related postmenopausal bone loss-a population-based approach," Osteoporosis International, vol. 17, no. 5, pp. 775-782, 2006.

[143] N. Yoshimura, T. Hashimoto, S. Morioka, K. Sakata, T. Kasamatsu, and C. Cooper, "Determinants of bone loss in a rural Japanese community. The Taiji study," Osteoporosis International, vol. 8, no. 6, pp. 604-610, 1998.

[144] T. V. Nguyen, P. N. Sambrook, and J. A. Eisman, "Bone loss, physical activity, and weight change in elderly women: the dubbo osteoporosis epidemiology study," Journal of Bone and Mineral Research, vol. 13, no. 9, pp. 1458-1467, 1998.

[145] C. Brot, L. B. Jensen, and O. H. Sørensen, "Bone mass and risk factors for bone loss in perimenopausal Danish women," Journal of Internal Medicine, vol. 242, no. 6, pp. 505-511, 1997.

[146] C. De Laet, J. A. Kanis, A. Odén et al., "Body mass index as a predictor of fracture risk: a meta-analysis," Osteoporosis International, vol. 16, no. 11, pp. 1330-1338, 2005.

[147] J. Sirola, H. Kröger, R. Honkanen et al., "Risk factors associated with peri- and postmenopausal bone loss: does HRT prevent weight loss-related bone loss?" Osteoporosis International, vol. 14, no. 1, pp. 27-33, 2003.

[148] H. Blain, A. Vuillemin, F. Guillemin et al., "Serum leptin level is a predictor of bone mineral density in postmenopausal women," Journal of Clinical Endocrinology and Metabolism, vol. 87, no. 3, pp. 1030-1035, 2002.

[149] M. Yamauchi, T. Sugimoto, T. Yamaguchi et al., "Plasma leptin concentrations are associated with bone mineral density and the presence of vertebral fractures in postmenopausal women," Clinical Endocrinology, vol. 55, no. 3, pp. 341-347, 2001.

[150] M. O. Premaor, L. Pilbrow, C. Tonkin, R. A. Parker, and J. Compston, "Obesity and fractures in postmenopausal women," Journal of Bone and Mineral Research, vol. 25, no. 2, pp. 292-297, 2010.

[151] H. H. Bolotin, "A new perspective on the causal influence of soft tissue composition on DXA-measured in vivo bone mineral density," Journal of Bone and Mineral Research, vol. 13, no. 11, pp. 1739-1746, 1998.

[152] F. Lauretani, S. Bandinelli, C. R. Russo et al., "Correlates of bone quality in older persons," Bone, vol. 39, no. 4, pp. 915921, 2006.

[153] D. N. Proctor, L. J. Melton, S. Khosla, C. S. Crowson, M. K. O'Connor, and B. L. Riggs, "Relative influence of physical activity, muscle mass and atrength on bone density," Osteoporosis International, vol. 11, pp. 944-952, 2000. 
[154] J. Rittweger, G. Beller, J. Ehrig et al., "Bone-muscle strength indices for the human lower leg," Bone, vol. 27, no. 2, pp. 319$326,2000$.

[155] H. M. Frost, "Bone's mechanostat: a 2003 update," Anatomical Record Part A, vol. 275, no. 2, pp. 1081-1101, 2003.

[156] P. Kortebein, A. Ferrando, J. Lombeida, R. Wolfe, and W. J. Evans, "Effect of 10 days of bed rest on skeletal muscle in healthy older adults," Journal of the American Medical Association, vol. 297, no. 16, pp. 1772-1774, 2007.

[157] J. S. W. Lee, T. W. Auyeung, T. Kwok, E. M. C. Lau, P. C. Leung, and J. Woo, "Associated factors and health impact of sarcopenia in older Chinese men and women: a crosssectional study," Gerontology, vol. 53, no. 6, pp. 404-410, 2008.

[158] M. Sheffield-Moore, C. W. Yeckel, E. Volpi et al., "Postexercise protein metabolism in older and younger men following moderate-intensity aerobic exercise," American Journal of Physiology, vol. 287, pp. E513-E522, 2004.

[159] A. R. Coggan, R. J. Spina, D. S. King et al., "Skeletal muscle adaptations to endurance training in 60- to 70-yr-old men and women," Journal of Applied Physiology, vol. 72, no. 5, pp. 1780-1786, 1992.

[160] N. Charifi, F. Kadi, L. Féasson, and C. Denis, "Effects of endurance training on satellite cell frequency in skeletal muscle of old men," Muscle and Nerve, vol. 28, no. 1, pp. 8792, 2003.

[161] S. L. Charette, L. McEvoy, G. Pyka et al., "Muscle hypertrophy response to resistance training in older women," Journal of Applied Physiology, vol. 70, no. 5, pp. 1912-1916, 1991.

[162] D. L. Hasten et al., "Resistence exercise acuteky increases MHC and mioxed muscle protein synthesis rates in 78-84 and 23-32 yr olds," American Journal of Physiology, vol. 265, pp. E620-E626, 1993.

[163] A. C. Jozsi, W. W. Campbell, L. Joseph, S. L. Davey, and W. J. Evans, "Changes in power with resistance training in older and younger men and women," Journals of Gerontology Series A, vol. 54, no. 11, pp. M591-M596, 1999.

[164] S. Welle, C. Thornton, and M. Statt, "Myofibrillar protein synthesis in young and old human subjects after three months of resistance training," American Journal of Physiology, vol. 268, no. 3, pp. E422-E427, 1995.

[165] M. A. Fiatarone, E. F. O’Neill, N. D. Ryan et al., "Exercise training and nutritional supplementation for physical frailty in very elderly people," New England Journal of Medicine, vol. 330, no. 25, pp. 1769-1775, 1994.

[166] K. E. Yarasheski, J. Pak-Loduca, D. L. Hasten, K. A. Obert, M. B. Brown, and D. R. Sinacore, "Resistance exercise training increases mixed muscle protein synthesis rate in frail women and men $\geq 76$ yr old," American Journal of Physiology, vol. 277, no. 1, pp. E118-E125, 1999.

[167] F. M. Ivey, S. M. Roth, R. E. Ferrell et al., "Effects of age, gender, and myostatin genotype on the hypertrophic response to heavy resistance strength training," Journals of Gerontology Series A, vol. 55, no. 11, pp. M641-M648, 2000.

[168] M. E. Cress et al., "Exercise: effects of physical functional performance in independent older adults," Journals of Gerontology Series A, vol. 55, pp. 641-648, 2000.

[169] C. A. Raguso, U. Kyle, M. P. Kossovsky et al., "A 3-year longitudinal study on body composition changes in the elderly: role of physical exercise," Clinical Nutrition, vol. 25, no. 4, pp. 573-580, 2006.

[170] A. A. Sayer, H. E. Syddall, H. J. Martin, E. M. Dennison, F. H. Anderson, and C. Cooper, "Falls, sarcopenia, and growth in early life: findings from the hertfordshire cohort study,"
American Journal of Epidemiology, vol. 164, no. 7, pp. 665671, 2006.

[171] A. A. Sayer, H. E. Syddall, H. J. Gilbody, E. M. Dennison, and C. Cooper, "Does sarcopenia originate in early life? Findings from the Hertfordshire Cohort Study," Journals of Gerontology Series A, vol. 59, no. 9, pp. 930-934, 2004.

[172] S. Kaptoge, N. Dalzell, R. W. Jakes et al., "Hip section modulus, a measure of bending resistance, is more strongly related to reported physical activity than BMD," Osteoporosis International, vol. 14, no. 11, pp. 941-949, 2003.

[173] C. H. Turner, Y. Takano, and I. Owan, "Aging changes mechanical loading thresholds for bone formation in rats," Journal of Bone and Mineral Research, vol. 10, no. 10, pp. 1544-1549, 1995.

[174] M. R. Forwood and D. B. Burr, "Physical activity and bone mass: exercises in futility?" Bone and Mineral, vol. 21, no. 2, pp. 89-112, 1993.

[175] B. A. Wallace and R. G. Cumming, "Systematic review onb randomised trials of the effect of exercise on bone mass in pre- and postmenopausal women," Calcified Tissue International, vol. 67, pp. 10-18, 2000.

[176] J. Sirola, T. Rikkonen, M. Tuppurainen, J. S. Jurvelin, and H. Kröger, "Association of grip strength change with menopausal bone loss and related fractures: a populationbased follow-up study," Calcified Tissue International, vol. 78, no. 4, pp. 218-226, 2006.

[177] J. Sirola, M. Tuppurainen, R. Honkanen, J. S. Jurvelin, and H. Kröger, "Associations between grip strength change and axial postmenopausal bone loss-a 10-year populationbased follow-up study," Osteoporosis International, vol. 16, no. 12, pp. 1841-1848, 2005.

[178] B. J. Kiratli, "Immobilization osteopenia," in Osteoporosis, R. Marcus, D. Feldman, and J. Kelsey, Eds., pp. 833-853, Academic Press, San Diego, Calif, USA, 1996.

[179] J. Sirola and T. Rikkonen, "Muscle performance after the menopause-review," Journal of the British Menopause Society, vol. 16, no. 12, pp. 1841-1848, 2005.

[180] M. Kärkkäinen, T. Rikkonen, H. Kröger et al., "Physical tests for patient selection for bone mineral density measurements in postmenopausal women," Bone, vol. 44 , no. 4, pp. 660 665, 2009.

[181] M. Kärkkäinen, T. Rikkonen, H. Kröger et al., "Association between functional capacity tests and fractures: an eight-year prospective population-based cohort study," Osteoporosis International, vol. 19, no. 8, pp. 1203-1210, 2008.

[182] D. Bonaiuti, B. Shea, R. Iovine et al., "Exercise for preventing and treating osteoporosis In postmenopausal women (review)," Cochrane Reviews, no. 1, 2009.

[183] R. U. Simpson, G. A. Thomas, and A. J. Arnold, "Identification of 1,25-dihydroxyvitamin D3 receptors and activities in muscle," Journal of Biological Chemistry, vol. 260, no. 15, pp. 8882-8891, 1985.

[184] G. Mingrone, A. V. Greco, M. Castagneto, and G. Gasbarrini, "A woman who left her wheelchair," Lancet, vol. 353, no. 9155, p. 806, 1999.

[185] P. M.F. Campbell and T. J. Allain, "Muscle strength and vitamin D in older people," Gerontology, vol. 52, no. 6, pp. 335-338, 2006.

[186] K. A. Ward, G. Das, J. L. Berry et al., "Vitamin D status and muscle function in post-menarchal adolescent girls," Journal of Clinical Endocrinology and Metabolism, vol. 94, no. 2, pp. 559-563, 2009.

[187] H. A. Bischoff-Ferrari, T. Dietrich, E. J. Orav et al., "Higher 25-hydroxyvitamin D concentrations are associated with 
better lower-extremity function in both active and inactive persons aged $\geq 60 \mathrm{y}$," American Journal of Clinical Nutrition, vol. 80, no. 3, pp. 752-758, 2004.

[188] I. S. Wicherts, N. M. van Schoor, A. J. Boeke et al., "Vitamin D status predicts physical performance and its decline in older persons," The Journal of Clinical Endocrinology and Metabolism, vol. 92, pp. 2058-2065, 2007.

[189] D. Bunout, G. Barrera, L. Leiva et al., "Effects of vitamin D supplementation and exercise training on physical performance in Chilean vitamin D deficient elderly subjects," Experimental Gerontology, vol. 41, no. 8, pp. 746-752, 2006.

[190] H. A. Bischoff-Ferrari, H. B. Stähelin, W. Dick et al., "Effects of vitamin D and calcium supplementation on falls: a randomized controlled trial," Journal of Bone and Mineral Research, vol. 18, no. 2, pp. 343-351, 2003.

[191] M. Pfeifer, B. Begerow, H. W. Minne, K. Suppan, A. Fahrleitner-Pammer, and H. Dobnig, "Effects of a longterm vitamin $\mathrm{D}$ and calcium supplementation on falls and parameters of muscle function in community-dwelling older individuals," Osteoporosis International, vol. 20, no. 2, pp. 315-322, 2009.

[192] J. K. Dhesi, L. M. Bearne, C. Moniz et al., "Neuromuscular and psychomotor function in elderly subjects who fall and the relationship with vitamin D status," Journal of Bone and Mineral Research, vol. 17, pp. 891-897, 2002.

[193] H. A. Bischoff-Ferrari, M. Conzelmann, H. B. Stähelin et al., "Is fall prevention by vitamin D mediated by a change in postural or dynamic balance?” Osteoporosis International, vol. 17, no. 5, pp. 656-663, 2006.

[194] R. R. Kalyani, B. Stein, R. Valiyil, R. Manno, J. W. Maynard, and D. C. Crews, "Vitamin D treatment for the prevention of falls in older adults: systematic review and meta-analysis," Journal of the American Geriatrics Society, vol. 58, no. 7, pp. 1299-1310, 2010.

[195] M. Visser, D. J. H. Deeg, and P. Lips, "Low vitamin D and high parathyroid hormone levels as determinants of loss of muscle strength and muscle mass (Sarcopenia): the longitudinal aging study Amsterdam," Journal of Clinical Endocrinology and Metabolism, vol. 88, no. 12, pp. 5766-5772, 2003.

[196] B. Dawson-Hughes, "Calcium and vitamin D," in Primer on the Metabolic Bone Diseases and Disorders of Bone Metabolism, pp. 231-233, American Society for Bone and Mineral Research, 2008.

[197] H. A. Bischoff-Ferrari, D. P. Kiel, B. Dawson-HIghes et al., "Dietary calcium and serum 25-hydroxyvitamin D status in relation to bone mineral density among U.S. adults," Journal of Bone and Mineral Research, vol. 24, pp. 935-942, 2009.

[198] J. S. Adams, V. Kantorovich, C. Wu, M. Javanbakht, and B. W. Hollis, "Resolution of vitamin D insufficiency in osteopenic patients results in rapid recovery of bone mineral density," Journal of Clinical Endocrinology and Metabolism, vol. 84, no. 8, pp. 2729-2730, 1999.

[199] P. Garnero, F. Munoz, E. Sornay-Rendu, and P. D. Delmas, "Associations of vitamin D status with bone mineral density, bone turnover, bone loss and fracture risk in healthy postmenopausal women. The OFELY study," Bone, vol. 40, no. 3, pp. 716-722, 2007.

[200] L. Cooper, P. B. Clifton-Bligh, M. L. Nery et al., "Vitamin $\mathrm{D}$ supplementation and bone mineral density in early postmenopausal women," American Journal of Clinical Nutrition, vol. 77, no. 5, pp. 1324-1329, 2003.

[201] A. Avenell, W. J. Gillespie, L. D. Gillespie, and D. O'Connell, "Vitamin D and vitamin D analogues for preventing fractures associated with involutional and post-menopausal osteoporosis," Cochrane Database of Systematic Reviews, no. 2, Article ID CD000227, 2009.

[202] M. E. Tinetti, M. Speechley, and S. F. Ginter, "Risk factors for falls among elderly persons living in the community," New England Journal of Medicine, vol. 319, no. 26, pp. 1701-1707, 1988.

[203] M. C. Nevitt, S. R. Cummings, S. Kidd, and D. Black, "Risk factors for recurrent nonsyncopal falls. A prospective study," Journal of the American Medical Association, vol. 261, no. 18, pp. 2663-2668, 1989.

[204] V. S. Stel, J. H. Smit, S. M. F. Pluijm, and P. Lips, "Consequences of falling in older men and women and risk factors for health service use and functional decline," Age and Ageing, vol. 33, no. 1, pp. 58-65, 2004.

[205] M. T. Vogt, J. A. Cauley, M. M. Tomaino, K. Stone, J. R. Williams, and J. H. Herndon, "Distal radius fractures in older women: a 10-year follow-up study of descriptive characteristics and risk factors. The study of osteoporotic fractures," Journal of the American Geriatrics Society, vol. 50, no. 1, pp. 97-103, 2002.

[206] B. Kristiansen, G. Barfod, and J. Bredesen, "Epidemiology of proximal humeral fractures," Acta Orthopaedica Scandinavica, vol. 58, no. 1, pp. 75-77, 1987.

[207] W. C. Hayes, E. R. Myers, J. N. Morris, T. N. Gerhart, H. S. Yett, and L. A. Lipsitz, "Impact near the hip dominates fracture risk in elderly nursing home residents who fall," Calcified Tissue International, vol. 52, no. 3, pp. 192-198, 1993.

[208] S. R. Lord and J. A. Ward, "Age-associated differences in sensori-motor function and balance in community dwelling women," Age and Ageing, vol. 23, no. 6, pp. 452-460, 1994.

[209] M. E. Tinetti and C. S. Williams, "Falls, injuries due to falls, and the risk of admission to a nursing home," New England Journal of Medicine, vol. 337, no. 18, pp. 1279-1284, 1997.

[210] H. B. Menz, M. E. Morris, and S. R. Lord, "Foot and ankle characteristics associated with impaired balance and functional ability in older people," Journals of Gerontology Series A, vol. 60, no. 12, pp. 1546-1552, 2005.

[211] J. D. Moreland, J. A. Richardson, C. H. Goldsmith, and C. M. Clase, "Muscle weakness and falls in older adults: a systematic review and meta-analysis," Journal of the American Geriatrics Society, vol. 52, no. 7, pp. 1121-1129, 2004.

[212] A. J. Campbell, M. C. Robertson, M. M. Gardner, R. N. Norton, M. W. Tilyard, and D. M. Buchner, "Randomised controlled trial of a general practice programme of home based exercise to prevent falls in elderly women," British Medical Journal, vol. 315, no. 7115, pp. 1065-1069, 1997.

[213] M. C. Robertson, N. Devlin, M. M. Gardner, and A. J. Campbell, "Effectiveness and economic evaluation of a nurse delivered home exercise programme to prevent falls. 1: randomised controlled trial," British Medical Journal, vol. 322, no. 7288, pp. 697-701, 2001.

[214] M. C. Robertson, A. J. Cambell, M. M. Gardner, and N. Devlin, "Preventing injuries in older adults by preventing falls: a meta-analysis of individual level data," Journal of the American Geriatrics Society, vol. 50, pp. 905-911, 2002.

[215] L. Day, B. Fildes, I. Gordon, M. Fitzharris, H. Flamer, and S. Lord, "Randomised factorial trial of falls prevention among older people living in their own homes," British Medical Journal, vol. 325, no. 7356, pp. 128-131, 2002.

[216] M. E. Tinetti, "Preventing falls in elderly persons," New England Journal of Medicine, vol. 348, no. 1, pp. 42-49, 2003. 
[217] J. T. Chang, S. C. Morton, L. Z. Rubenstein et al., "Interventions for the prevention of falls in older adults: systematic review and meta-analysis of randomised clinical trials," British Medical Journal, vol. 328, no. 7441, pp. 680-683, 2004.

[218] S. Gates, J. D. Fisher, M. W. Cooke, Y. H. Carter, and S. E. Lamb, "Multifactorial assessment and targeted intervention for preventing falls and injuries among older people in community and emergency care settings: systematic review and meta-analysis," BMJ, vol. 336, no. 7636, pp. 130-133, 2008.

[219] O. J. De Vries, G. M. E. E. Peeters, P. J. M. Elders et al., "Multifactorial intervention to reduce falls in older people at high risk of recurrent falls: a randomized controlled trial," Archives of Internal Medicine, vol. 170, no. 13, pp. 1110-1117, 2010.

[220] K. M. Sanders, G. C. Nicholson, J. J. Watts et al., "Half the burden of fragility fractures in the community occur in women without osteoporosis. When is fracture prevention cost-effective?" Bone, vol. 38, no. 5, pp. 694-700, 2006.

[221] S. Kaptoge, L. I. Benevolenskaya, A. K. Bhalla et al., "Low BMD is less predictive than reported falls for future limb fractures in women across Europe: results from the European Prospective Osteoporosis Study," Bone, vol. 36, no. 3, pp. 387-398, 2005.

[222] T. Rikkonen, K. Salovaara, J. Sirola et al., "Physical activity slowsfemoral bone loss but promotes wrist fractures in postmenopausal women: a 15-year follow-up of the OSTPRE study," Journal of Bone and Mineral Research, vol. 25, pp. 2332-2340, 2010.

[223] L. P. Fried, C. M. Tangen, J. Walston et al., "Frailty in older adults: evidence for a phenotype," Journals of Gerontology Series A, vol. 56, no. 3, pp. M146-M156, 2001.

[224] J. M. Guralnik, L. Ferrucci, E. M. Simonsick, M. E. Salive, and R. B. Wallace, "Lower-extremity function in persons over the age of 70 years as a predictor of subsequent disability," New England Journal of Medicine, vol. 332, no. 9, pp. 556561, 1995.

[225] J. M. Guralnik, E. M. Simonsick, L. Ferrucci et al., "A short physical performance ba ttery assessing lower extremity function: association with self-reported disability and prediction of mortality and nursing home admission," Journal of Gerontology, vol. 49, pp. M85-M94, 1994.

[226] M. Cesari, C. Leeuwenburgh, F. Lauretani et al., "Frailty syndrome and skeletal muscle: results from the Invecchiare in Chianti study," American Journal of Clinical Nutrition, vol. 83, no. 5, pp. 1142-1148, 2006.

[227] G. Crepaldi and S. Maggi, "Sarcopenia and osteoporosis: a hazardous duet," Journal of Endocrinological Investigation, vol. 28, no. 10, supplement, pp. 66-68, 2005.

[228] Y. Rolland, G. Abellan Van Kan, A. Benetos et al., "Frailty, osteoporosis and hip fracture: causes, consequences and therapeutic perspectives," Journal of Nutrition, Health and Aging, vol. 12, no. 5, pp. 335-346, 2008.

[229] A. Frisoli, P. H. Chaves, S. J.M. Ingham, and L. P. Fried, "Severe osteopenia and osteoporosis, sarcopenia, and frailty status in community-dwelling older women: results from the Women's Health and Aging Study (WHAS) II," Bone, vol. 48, no. 4, pp. 952-957, 2011. 


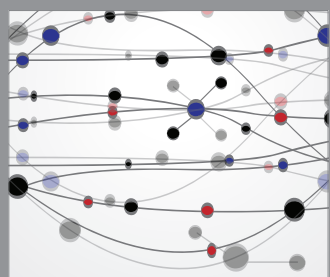

The Scientific World Journal
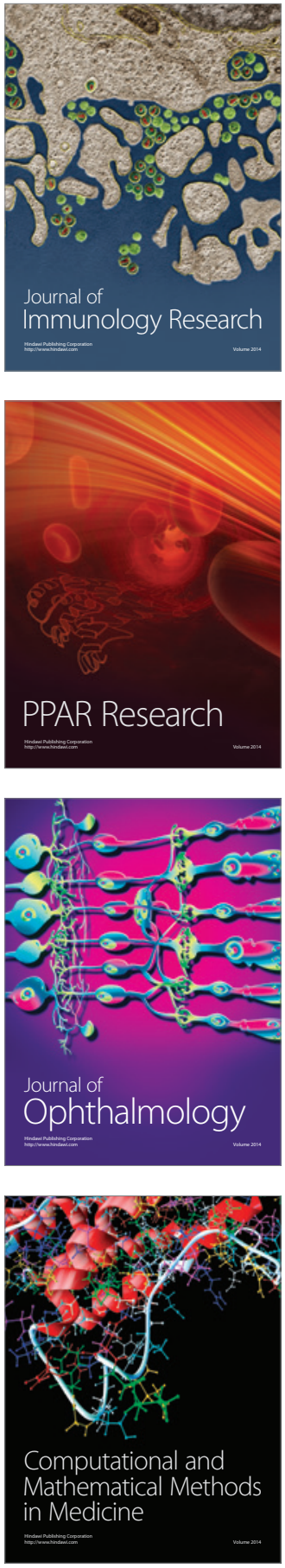

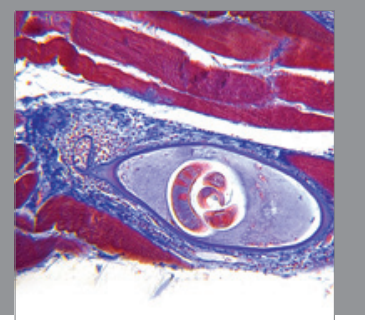

Gastroenterology

Research and Practice
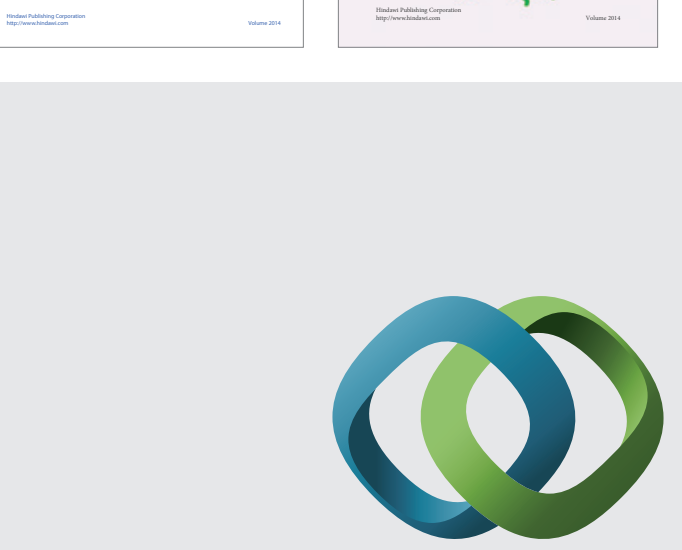

\section{Hindawi}

Submit your manuscripts at

http://www.hindawi.com
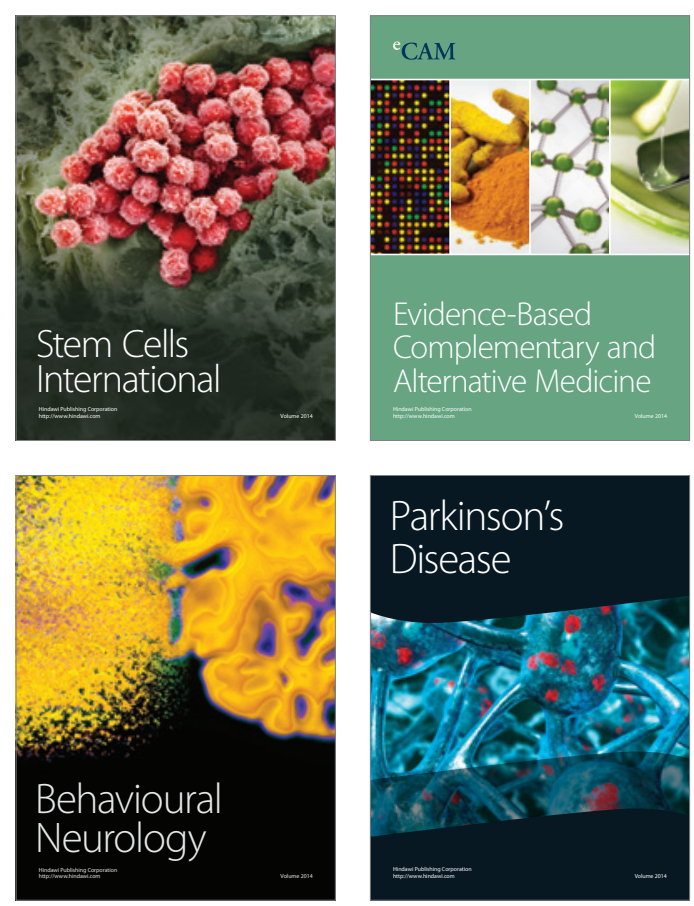

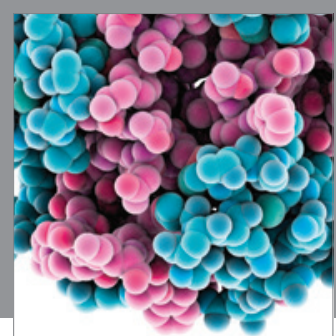

Journal of
Diabetes Research

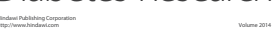

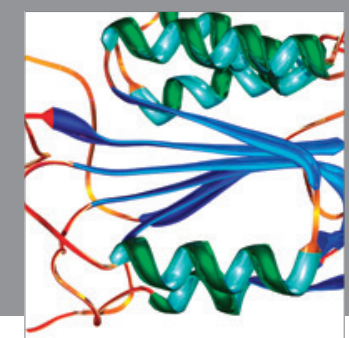

Disease Markers
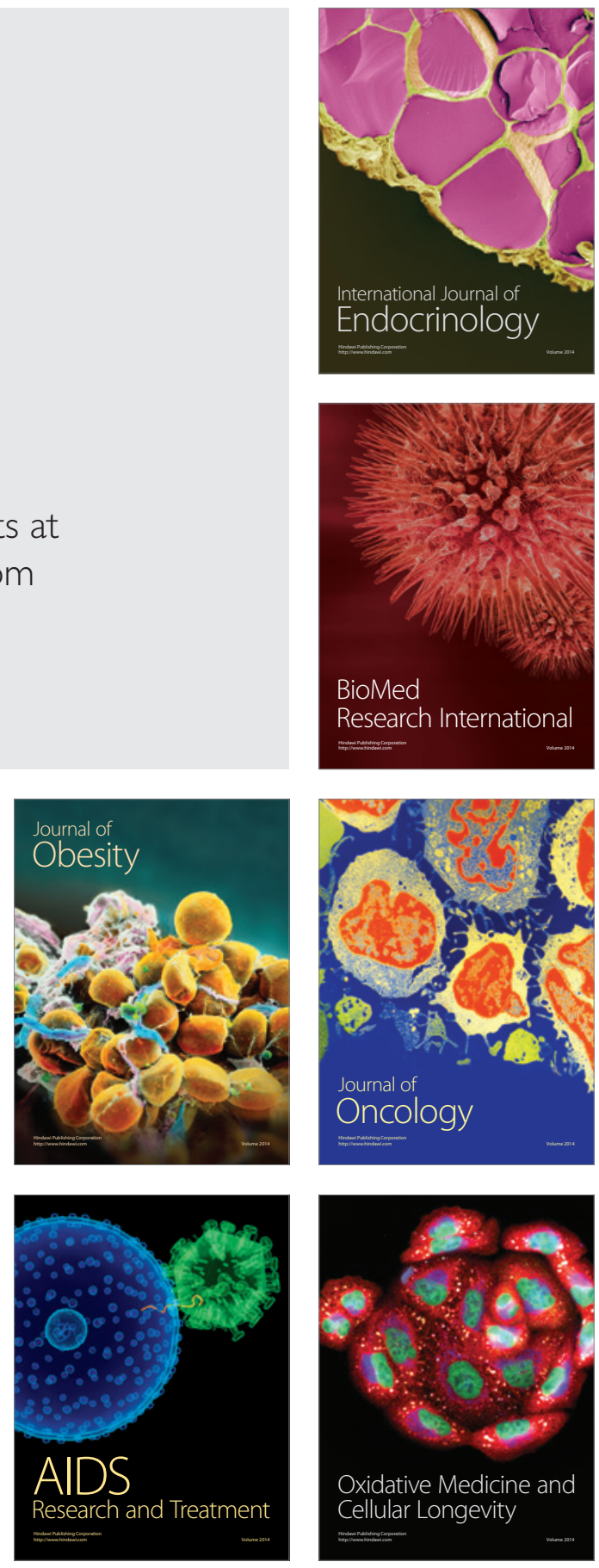